\title{
Factors Affecting Transfer of On-The-Job Training at Workplaces in Pakistan
}

\author{
Maham Fatima $^{1 *}$, Danish Ahmed Siddiqui ${ }^{2}$ \\ ${ }^{1}$ Research Scholar, Karachi University Business School, University of Karachi, PAKISTAN \\ ${ }^{2}$ Associate Professor, Karachi University Business School, University of Karachi, PAKISTAN \\ *E-mail for correspondence: mahamfatima551@gmail.com
}

https://doi.org/10.18034/abr.v10i1.457

\begin{abstract}
Purpose: This research is focused on examining the factors that influence transfer (effectiveness) of OnThe-Job training at workplaces in Pakistan. The study identifies the factors that affect transfer of OJT training included independent variables such as motivation to learn, Perceived Organizational Support and Training Design and their impact on employees' performance i.e. Transfer of Training.

Methodology: The study adopted quantitative research and data was collected through well-structured questionnaire. The sample of 200 participants were selected throughout Pakistan using convenience sampling technique. Smart PLS software was used to analyse the data through descriptive statistics, structural equation modelling and Confirmatory factor analysis.

Findings: The result revealed that there is a strong and significant impact of motivation to learn and training design on transfer of OJT training at workplaces in Pakistan. However, the results do not show any significant impact of Perceived Organizational Support in organizations on transfer of OJT training.

Conclusions: This shows that even though, if the organization support is not present, the motivation to learn new things and to implement it to the workplace and effectively designed training programs can overcome the issues.

Practical Implications: Organizations can use the result in favour of their organizational effectiveness, to consistently design effective training programs, and to consistently motivate their employees and to improve support and guidance by top management in the organizations.
\end{abstract}

Key words: OJT training, Transfer of Training, Motivation to Learn, Perceived Organizational Support and Training Design, Pakistan, SEM, CFA

\section{INTRODUCTION}

\section{Background of the study}

Training is the process of acquiring certain knowledge or skills, while development is the improvement of emotional and intellectual abilities and skills required for performing a job in a better way (David, 1997). A number of researchers have defined training as an experience based on planned learning in order to acquire a new set of skills, attitudes or knowledge (Baharim, 2005).

According to (Burke \& Saks, 2009), the role of top management, supervisor, trainer and trainee is very important throughout the process of training. All the stakeholder need to understand the extent to which they are responsible and accountable for the transfer process and the positive and negative outcome of their role.

Generally, training programs were developed for providing instructions on job-related tasks and for the orientation of new employees with the practices and goals of the organization (Greenhaus et al., 2000). Furthermore, researchers have also linked training with socializing new entrants into the best patterns and interactions of their jobs and the role they are required to play in the organization. Firms having training and development departments usually performed the role of communicating specific managerial and technical skills that employees were required to possess in order to advance to higher positions in their jobs. 
Training is considered as one of the most reliable and vital human resource practices for enhancing the productivity of employees as well as the organization (Kia \& Ismail, 2013). A study (Lim, 2000) indicated that organizations today are facing significant competition across the globe as more pressures and turbulence of continuously changing environment are imposed on them. In such competitive environment, firms are facing globalization of their businesses as well as their employees. This trend has also affected to a large extent the training and development of employees, to cope up with the global needs of employees' performances. This has led to a need of understanding the nature of training and knowledge transfers at workplace (Lim, 2000).

For achieving various organizational goals and tasks and for enhancing employees' performance, training programs need to be designed in ways that tend to create a win-win situation both on individual as well as organizational level (Elangovan \& Karakowsky, 1999). It is also highlighted by previous researchers that employees and organizations can achieve their goals only when skills learned through trainings are effectively implemented and transferred on job. It is argued by Acton \& Golden (2003) that employees' training and development is every essential for the operation and advancement of an organization. Furthermore, the same factors are both critical and crucial for an employee's career development and skills enhancement. It is further argued by Cheng \& Ho (2001) that a considerable amount of money and time is invested by organizations in the development of their human resources. The authors further highlighted that in today's increasing global competition, it is highly critical for organizations to continuously improve their employees' skills, attitudes, abilities and knowledge (Kauffeld \& Willenbrock, 2010). Therefore, several training professionals and researchers have focused on studying the factors that affect the transfer of training on job, such as transfer design, training design, wok environment, organization culture, trainees, training transfer motivation.

Researchers have also highlighted that a significant amount of investment is wasted on training and development by organizations, since majority of the skills and knowledge learned in training are not even used by employees on their job (Broad \& Newstrom, 1992); (Bhatti \& Kaur, 2010). However, to a great extent, research on transfer of training has faced obstacles by the conceptual lack of clarity. According to some researchers, even though, training is necessary, there are several factors that inhibit the transfer. In order to provide clarity about the transfer issue, Broad \& Newstrom (1992) focused on studying different factors that inhibit the transfer of training.

\section{Problem Statement}

One of the most reliable human resource method to increase and enhance the organizational productivity is Training (Bhatti \& Kaur, 2009). Organizations therefore invest a huge amount of money each year in on-the-job training programs but most of the employees (trainees) failed to transfer it to their workplaces. Current study is attempted due to this theoretical gap. A win- win situation for both employee and organization must be created by the effective design of training in order to accomplish organizational tasks and improve the employee efficacy. Employees and also organizations can achieve goals, if learning skills are transferred effectively to the workplace (Bhatti \& Kaur, 2010). The basic aim of training is to help organizations by providing, obtaining, and improving the necessary skills and this can be done only when OJT is retained and transferred by employees (trainees) at the workplaces.

The training transfer is a difficult challenge for organizations that are focusing on outcomes from the investments on training programs (Chiaburu, Sawyer, \& Thoroughgood, 2010b). In a study, researchers found that, the new learned knowledge, skills and attitudes had used by only 62 percent of employees right after training. After 6 months, it fell to 44 percent and further decreased to 34 percent after 1 year duration (Saks \& Belcourt, 2006). A recent study has been carried in which 56 trainees declares that the transfer performance of trainees fell within three weeks after training (Vermeulen \& Admiraal, 2009).

In different sectors of Pakistan, huge amount of money and labor is invested for OJT training programs, but results of these trainings are not satisfactory due to some individual and organizational factors that affect transfer of training back to the job by trainees. This study will help the organizations to understand the loopholes in training programs that couldn't allow the trainees to retain it and apply it on the workplaces

A number of studies have presented a serious issue persisting within firms, provided that transfer of training is highlighted as the major point of influence through which training can affect organizational results and outcomes (Saks \& Belcourt, 2006). Moreover, it has been widely acknowledged by researchers that transfer of training can only occur when the trainees have willingness and ability to learn and apply new knowledge and skills (Noe R. A., 2000). Majority of the employees in companies across the globe have been facing issues with transferring the training to their jobs. Whatever may be the actual standard of training, if the employees are unable to transfer the training skills, it is likely that they waste organization's as well as their own time and efforts. A huge amount is invested in training in order to increase the productivity so that businesses can sustain while facing fierce competition in the international market and are able to cope up with rapidly changing environment (Bates et al., 2000).

Ultimately, there is an absolute need to understand the factors that influence training transfer so that organizations can design appropriate strategies and plans to achieve maximum output from their investments on on-the-job training programs. 


\section{Gap Analysis}

Although, a number of studies have been focused on transfer of training, there is little evidence available on both individual as well as organizational factors that have a significant impact on transfer of skills and knowledge on job (Bhatti \& Kaur, 2010; Cheng \& Ho, 2001).

Different studies focus on single factor of organizational context i.e. Impact of organizational support on transfer of training. For example, (Colquitt et al., 2000) found that there is a positive impact of supportive transfer climate on transfer of training. In contrast, there is a negative impact of unsupportive transfer climate on transferring the new knowledge at work place (Aguinis \& Kraiger, 2009). Researchers (Foxon, 1993) and (Foxon, 1994) has found that the specific forces in environment like the management support perceptions are important factors of training transfer. Similarly, (Kia \& Ismail, 2013) in a research also focuses on just environmental factors and the relationship between training transfer and environmental characteristics among non-academic staff of a university in Malaysia.

Scholars have also found out separately that motivation to learn and organizational support are the most important factors that affects transfer of training (Baldwin \& Ford, 1988). In previous studies, specific trainees' characteristic and work environmental factors have been accessed separately to determine their effect on training transfer. (Awoniyi et al., 2002); (Lim \& Morris, 2006). But studying the effect of a specific characteristic in isolation may not be effective as mentioned by different scholars (Yamkovenko \& Holton, 2010). Also, the training characteristics e.g. 'training design' impact on transfer of OJT training has not properly studied in same platform with trainee characteristics and work environment characteristics. A study Gill et al. (2016) carried out a research on Determinants of training transfer in the wine industry in Rioja, Spain. Here he worked on training design, trainee responses and work environment factors by choosing few variables. But this study is limited to only one sector in Spain.

Lim (2000) carried out a research on Training Design Factors Influencing Transfer of Training to the Workplace within an International Context, to examine the degree of learning and training transfer achieved by HRD professionals of SK Group in Korea, and to identify what factors in training design affect the learning and transfer of training. It appeared that trainee personality variables influenced the learning and training transfer, but were not explored in this study. Here, the research was limited to the international context and trainee characteristics and environmental factors are not considered.

Especially in Pakistan, studies do not include both individual and organizational factors that affect transfer of training. Therefore, the study carried in this research paper is directed to help address this gap by studying the mutual effects of motivation to learn i.e. a trainee characteristic, perceived organizational support (POS) i.e. work environmental factor and training design i.e. a training characteristic, on training transfer at the workplaces in Pakistan. It will then cover both individual as well as organizational factors which seems to effect simultaneously but were not previously covered in single study in Pakistan.

\section{Research Objectives}

The aim of this research is to identify the factors that affect transfer of training in different organizations of Pakistan to enhance the effectiveness of training and its transfer in the workplaces to ensure better productivity and outcomes.

The scope of this study is limited to industries of Pakistan because of highly uncertain and competitive environment in these industries, where employees are required to continuously develop their skills and learn innovative ways to perform different processes.

\section{Research Question(s)}

- What are the major factors and roadblocks that affect transfer of OJT training?

- What is the impact of training design, trainee characteristics like motivation to learn, and work environment in the form of perceived organizational support on transfer of OJT training?

\section{Significance of the Study}

There is little evidence available on transfer of training in workplaces in Pakistan, hence, the study will contribute practice and theoretical knowledge related to the factors that affect transfer of knowledge from training to job. This research will help in adding new information to the literature base. The study will contribute to different business sectors in learning about various factors that affect transfer of training, which will enable them to optimize their organization's strategy. The study will also help in enhancing managements' understanding of the workplace related factors to provide a conducive environment for both trainees as well as trainers. The recommendations provided in this study based on various factors identified will help the policy makers, human resource people and top management in developing strategies and effective training programs.

It will also allow the organizations to understand the aspects that training should be properly designed and implemented rightly and must be flexible and involves participatory method to avoid difficulties faced by trainees in transferring it on jobs. This Study will make organizations to develop supportive environment so that employees willingly make their contributions without any pressure and apply learned knowledge on their job roles by considering their organizations as their own place. Also, one of the main objective is to induce such an 
environment in which trainee's level of motivation to learn and to implement boosts to the higher levels which intern increases job satisfaction.

\section{Definition of Key Terms}

Transfer of training: it is the extent to which trainees apply their skills, attitudes, and knowledge acquired in a training to their jobs (Geilen, 1996).

On-the-Job training: it refers to a non-structured or structured method of training that occurs at the workplace, while performing the task practically (Rothwell \& Kazanas, 1994).

\section{LITERATURE REVIEW AND HyPOTHESIS DEVELOPMENT}

\section{Definition of Training and Transfer of Training}

Greenhaus, Callanan, \& Godshalk (2000) in their 'Model of Career Management', explained the term training through three different approaches:

1) working while training, which involved a formally designed training program, rotation of new employees within different departments and projects and working on challenging projects; 2) training while working, which involved apprenticeship of employees within the same unit;

3) And full-time training, which involved training department to observe and oversee the rotations new entrant through various departments and many times assigns them special projects.

However, it is important to ensure that employees are able to create a learning environment in order to make the training effective. The second step in ensuring the effectiveness of training is the application of skills and knowledge acquire during the training session in their job settings. This step is defined as the transfer of training concept that refers to the trainees' ability to continuously apply what they have learned and acquired during the training (such as cognitive strategies, skills, knowledge, behaviours) effectively in performing job-related tasks (Noe, Hollenbeck, Gerhart, \& Wright, 2006).

\section{Transfer of training}

Park \& Wentling (2007) defined transfer of training as the extent to which trainees apply and generalize skills, abilities and knowledge to their jobs. Nikandrou, Brinia, \& Bereri (2009) highlighted that for understanding the process of transfer of training, one should identify and analyze all the factors that affect trainees during and after the training sessions.

Laker (1990) introduced 2 forms of transfer: 1) near transfer; and 2) far transfer. Far transfer shows that the acquired knowledge is utilized in irrelevant working conditions, while near transfer indicates the use of learned knowledge in situations that are similar to the training programs. Clark \& Voogel (1985) explained that near transfer occurs when trainers tend to focus on practical relevancy of the training contents, i.e. when training contents and activities are similar to actual jobs, people can achieve maximum level of transfer of training. According to Lim \& Johnson (2002), training design, instructional strategies, and content should be relevant to the objectives of transfer. Far and near transfer are viewed by Nikandrou et al. (2009) as indirect and direct transfer. The researchers further highlighted that the trained employees can apply the skills and knowledge acquired to their work in direct transfer, while indirect transfer suggest that trained employees might use their skills in the workplace.

\section{Factors affecting transfer of training}

Bhatti \& Kaur (2010) conducted a research to identify the impact of training designs and individual factors of the transfer of training. Their research findings highlighted that perceived content validation can play an important role in developing positive reaction among trainees and increase the performance of self-efficacy among them. Moreover, the research findings proposed that perceived content validity and transfer design increased the performance of self-efficacy among trainees that results in maximizing the transfer of training through motivation.

Saleh (2011) focused on identifying that influence transfer of training in the working environment from employees' perspective. His research findings concluded that work environment, trainee characteristics, trainer attributes, training deign, and organizational culture are significantly related to the transfer of training. The researcher further suggested that it is essential to examine all the factors of training process in future.

Lim (2000) conducted a research attempted to examine the impact of the training design on the transfer process of training provided by human resource development (HRD) in a multinational company. The researcher studied the training project of a Korean company. The research findings revealed that in the needs of trainees may vary in the cross cultural trainings. Therefore, the more satisfied the individual is from the training, the better the chances of positive transfer of training. Additionally, using diverse instructional methods was identified as a vital strategy for deigning training program that can lead to successful transfer of training. He also highlighted that trainees can excel the training content experientially and conceptually if the learning experiences are provided in diversified ways.

Kia \& Ismail (2013) conducted a research for investigating the relation between transfer of training and environment characteristics among the non-academic staff of a university. The research findings demonstrated a significantly positive relation between transfer of training and all the dimensions of environmental characteristics. 
Lim \& Morris (2006) highlighted that a supportive organizational culture involved the degree to which top management, supervisors, colleagues, and trainers help in optimizing the use of skills, attitudes, and knowledge gained by trainees in training sessions to their job-related tasks.

Zumrah \& Boyle (2015) highlighted that job satisfaction and perceived organizational support play an important role in the effective transfer of training in organizations. The research findings highlighted that job satisfaction serves as a mediating factor in the relation between transfer of training and perceived organizational support. A research conducted by (Chiaburu \& Marinova, 2005) highlighted a positive relation between self-efficacy and pre-training motivation, predicting transfer of training. Providing similar conclusion, (Chiaburu \& Lindsay, 2008) examined the role of self-efficacy in training transfer.

Shad (2008) conducted a research to determine the impact of work environment on the transfer of skills, attitudes and knowledge acquired in training sessions. A sample size of 237 employees in 357 branches of banks of Islamabad and Rawalpindi was selected to conduct the survey. The research findings show that there is a positive relation between management support, peer support, opportunities available to employees, aesthetic and physical environment, and workload and transfer of training. Kim-Soon et al. (2014) identified that work environment has significant impact on motivation to learn and perceived training transfer. According to (Lim \& Morris, 2006) transfer of training is restricted or hindered when trainees do not get enough opportunities to apply the learned skills. Furthermore, (Gilpin-Jackson \& Bushe, 2007) showed that it is critical to provide adequate time to transfer training otherwise it hinders transfer.

Relationship between Transfer of Training and Motivation to Learn

Motivation to transfer has been considered as an outcome variable of motivation to learn as per many studies (Burke \& Hutchins, 2007). Highly motivated employees are more productive and performs their level best as per the researchers. These employees who are reliable and highly skilled are considered as an asset for the organization (Waiyaki, 2017). Employees' commitment to their work and the amount of energy they exert on their jobs reflect to employees' motivation. Herzberg et al. (1959) described employee motivation as "performing a work-related action because you want to".

Workplace environment must be like where employees want to be committed, stay long and considers organizations' growth as their growth (Waiyaki, 2017). The human resource is equally important as financial resources to the organization. The growth of workforce is the growth of the organization therefore, the employees must be dealt with attention and humbleness (Cowling \& Mailer, 2013). One of the important factor on which transfer of training by trainees and employee performance is based is employee motivation. As soon as level of motivation increases, employee's willingness to take responsibilities and involvement in job also increases with the increase in performance. Satisfaction rises with the training is the reason that Learning through trainings affect the motivation of employees (Rowden \& Conine, 2005) and more contented employees lead to good performance (Tsai \& et al, 2007).

Motivation of the employee is not only the responsibility of line manager but the joint efforts of line manager, top management, immediate boss of the employee and on employee itself (Bhuvanaiah \& Raya, 2015). For enhancing the performance of employees, they can be motivated at the same time with both intrinsic as well as extrinsic motivation (Amabile, 1996). Study by Kim-Soon et al. (2014) suggests that there is a great impact of work environment on perceived transfer of training and learning motivation.

There is a positive relation between self-efficacy and pretraining motivation in prediction of training transfer by employees as stated in the research of (Chiaburu \& Marinova, 2005). Chiaburu \& Lindsay (2008) also provides the same results by examining the role of self-efficacy in transfer of training by employees. Another investigative research concluded that motivation to learn of trainees is the strongest factor of positive outcomes of training (Tziner et al., 2007).

In a research conducted by Nikandrou et al. (2009), there is a significant role of characteristics of trainees in training transfer. Another investigative research conducted by Tziner et al. (2007) shows the same conclusion that trainees' motivation to learn was found to be the strongest determinant of positive training outcomes. Following hypothesis is proposed on the basis of above mentioned studies:

$\mathrm{H}_{1}$ : There is a direct impact of motivation to learn on transfer of OJT training.

Relationship between Transfer of Training and Perceived Organizational Support (POS)

According to Baldwin et al. (2009), active participation and commitment from management includes setting learning objectives and providing feedbacks. Nawaz et al. (2013) focused on determining the effect of professional growth on experiences, knowledge and skills of employees through training. They adopted a co-deductive research method. A sample size of 100 employees from 20 branches of 7 banks in Bahawalpur was selected. The research revealed that commitment level of top management has significant impact on professional growth of employees to boost their knowledge and capabilities.

For the growth of employees' positive attitudes and good peer relationships and commitment to jobs, POS is extremely essential. Employee's job commitment and involvement as well as satisfaction increases as a result of 
high POS as indicated by previous studies. When the employee feel that their organization values their hard work and cares about their well-being, they put much more effort and give their full loyalty to the organization (Lavelle et al., 2009) and this will then produce a more constructive transfer of training results to their organization (Zumrah et al., 2012).

There is a positive relationship between supervisor support and transfer of training as mentioned in various previous studies. For example, (Xiao, 1996) concluded that level of supervision to be the most important interpreter of positive transference by completing a numerical study of women working in production groups in electronics manufacturing corporations. Communication between trainee and supervisor is the most important factor in the work environment affecting training transfer (Lim \& Johnson, 2002). Brinkerhoff \& Montesino (1995) examine transfer of training in training programs on behavioural skills, compared trainees who received support and guidance and trainees who did not, and results show transfer to be much greater for the group that received support and assistance. Seyler et al. (1998) carried an experiential study of environmental factors of motivation that affects training transfer. The environmental influences of motivation that took into account are: opportunities for utilization of training, peer support, supervisor approval and supervisor support. Support of supervisors is significantly associated to motivation to transfer as indicated by the outcomes of this study.

Chiaburu et al. (2010) and Tracey et al. ( 2001) concluded that trainees/employees that work in a supportive environment indicated higher stages of pre-training selfefficacy and pre-training motivation and was found to transfer training on their jobs with no difficulties. Al-Eisa et al. (2009) also examined the effect of self-efficacy as an individual characteristic and supervisor support as an organizational level aspect on transfer intent. Chiaburu et al. (2010) carried a study that confirmed the hypothesis that supervisor support is positively linked to individual aspects like training self-efficacy, motivation to transfer and learning goal orientation which further affected training transfer. Supervisors also greatly affect their subordinates' goal orientation, which may linked to improved performance and better transfer of training (Chiaburu et al., 2010).

Following hypothesis is proposed on the basis of above mentioned studies:

$\mathrm{H}_{2}$ : There is a direct impact of perceived organizational support on transfer of OJT training.

\section{Relationship between Transfer of Training and Training Design}

The training procedure is carried by means of a training plan, which is a document enlisted by the firm to deliver personnel training for a particular period (Fernandez-
Salinero, 1999). A training plan eventually respond to organizational needs and aims for the continuous betterment of employee abilities and qualifications. To guide the process of conducting training activities is the main purpose of design. The process in which training designers carried a number of steps for solving a training problem and adapt the particular strategy to the organization's specific circumstances is 'design of training activities' (Tres, 2002).

The Characteristics of the learning environment is referred to training design (Noe R. , 2009). Some features of training design like compensation for training, distributive justice and learner-centered learning are applied to expand learning motivation concluded by different studies (Whitehill \& Mcdonald, 1993); (Bell \& Ford, 2007); (Nikandrou et al., 2009). A fair training program that comprises specific guidelines and information, a sincere concern for employee hopes and expectations, and the formation of an ethical foundation where moral behaviours are the basis for any dealing is referred to distributive justice (Quinones, 1997). Learning emphases on helping individuals in attaining strategies to improve their opportunities for self-knowledge, for example, to apply means-centered strategies.

There must be the careful planning of training for the success of training programs and ultimately for the training transfer at the workplaces. (Nikandrou et al., 2009). Training Motivation has been proven to be stimulated by training design (Gegenfurtner et al., 2009) and it is also vital to the fruitful training transfer by employees to their jobs (Axtell et al., 1997); (Kontoghiorghes, 2002) ; (Rouiller \& Golstein, 1993).

Wawira (2014) focused on identifying factors that affect transfer of knowledge acquired during training to the job in commercial banks of Kenya. According to the research findings, provision of supportive or additional guidance on application of skills on job, training guidelines and content significantly affected transfer of knowledge. Furthermore, trainer's professional experience and knowledge of the topic also affected the transfer of knowledge.

Bhatti et al. (2013) conducted a research to analyse the importance and role of factors related to training design and individual performance in transfer of training process. According to the research findings, perceive content validity and transfer design improved selfefficacy performance of trainees. In addition, the researchers noted that self-efficacy plays a mediating role in transfer motivation, perceived content validity and transfer design.

Following hypothesis is proposed on the basis of above mentioned studies:

$\mathrm{H}_{3}$ : There is a direct impact of training design on transfer of OJT training. 
Conceptual Framework

\section{Motivation \\ to Learn}
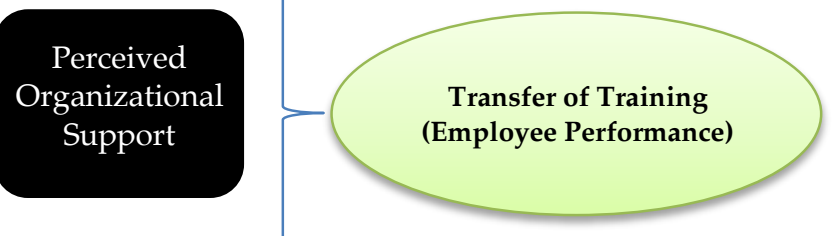

Training

Design

Figure 1: Relationship between dependent and independent variables

The conceptual framework clearly show that training design, motivation to learn and perceived organizational support have a significant relationship with employees performance. Here transfer of training is a dependent variable where as training design, motivation to learn and perceived organizational support are independent variable that can have a strong and weak relationship.

\section{Research Methodology}

Sampling Technique and Sample Size

The sampling technique that was used for this research is convenience sampling, based on which the data was collected on the basis of convenience of approachability. Convenience sampling is a non-probability sampling technique, which enables the research to collect data from the most easily approachable participants. Sample of 200 employees has taken in this study.

\section{Data Collection Method}

Primary data was collected for this study. The data was collected using questionnaire survey, which were filled by employees of companies. Structured and formal, selfadministered survey questionnaire was developed which included statements based on 5-point Likert scale. These statements were developed by referring to previous studies conducted on factors affecting transfer of training.

The four questions of Transfer of Training variable and four questions of Perceived Organizational Support variable are adopted from Gill et al. (2016). The first question of Motivation to Learn variable is adopted from Gill et al. (2016) and other four questions of this variable are adopted Kim-Soon et. Al., (2014). The first two questions of Training Design variable were again adopted from Gill et al. (2016) and other three questions of this variable are adopted from Lim (2000).
First the instrument was developed and was reviewed by the supervisor for ensuring that it is understandable and comprehensive. Participants were briefly informed about the research aim and background. The participants were ensured that their information will be kept confidential and will not be disclosed.

Data Integration Method

For answering the research questions, the data collected using questionnaire surveys was analysed through Smart PLS Software. Deductive methods were used for this study. Responses are analysed using descriptive statistics, confirmatory factor analysis and structural equation modelling.

\section{DATA ANALYSIS}

Table 1: Descriptive Statistics of demographic information

\begin{tabular}{|c|c|c|c|}
\hline $\begin{array}{c}\text { Respondents } \\
\text { demographic } \\
\text { profile }\end{array}$ & Groups & Frequency & Percentage \\
\hline \multirow{4}{*}{$\begin{array}{l}\text { Level/Grade } \\
\text { of } \\
\text { respondents }\end{array}$} & Managerial Level & 85 & $42.5 \%$ \\
\hline & Assistant Level & 65 & $32.5 \%$ \\
\hline & Officer Level & 36 & $18 \%$ \\
\hline & Others & 14 & $7 \%$ \\
\hline \multirow{5}{*}{$\begin{array}{l}\text { Sector of } \\
\text { respondents' } \\
\text { organization }\end{array}$} & Textile Sector & 45 & $22.5 \%$ \\
\hline & $\begin{array}{l}\text { Banking and } \\
\text { Finance Sector }\end{array}$ & 65 & $32.5 \%$ \\
\hline & $\begin{array}{l}\text { Manufacturing } \\
\text { Sector }\end{array}$ & 35 & $17.5 \%$ \\
\hline & Software & 24 & $12 \%$ \\
\hline & Others & 31 & $15.5 \%$ \\
\hline \multirow[t]{2}{*}{ Gender } & Female & 62 & $31 \%$ \\
\hline & Male & 138 & $69 \%$ \\
\hline \multirow[t]{5}{*}{ Age } & Less than 25 & 55 & $27.5 \%$ \\
\hline & $25-30$ & 97 & $48.5 \%$ \\
\hline & $31-35$ & 35 & $17.5 \%$ \\
\hline & $36-40$ & 8 & $4 \%$ \\
\hline & Greater than 40 & 5 & $2.5 \%$ \\
\hline \multirow[t]{4}{*}{ Qualification } & Bachelors & 73 & $36.5 \%$ \\
\hline & Masters & 113 & $56.5 \%$ \\
\hline & M.Phil/PhD & 11 & $5.5 \%$ \\
\hline & Others & 3 & $1.5 \%$ \\
\hline \multirow{6}{*}{$\begin{array}{l}\text { Length of } \\
\text { Service }\end{array}$} & Less than a Year & 40 & $20 \%$ \\
\hline & $1-2$ years & 0 & - \\
\hline & $2-5$ years & 53 & $26.5 \%$ \\
\hline & $5-6$ years & 18 & $9 \%$ \\
\hline & $6-10$ years & 78 & $39 \%$ \\
\hline & More than 10 years & 11 & $5.5 \%$ \\
\hline \multirow{5}{*}{$\begin{array}{l}\text { Monthly } \\
\text { Income }\end{array}$} & Less than $25,000 \mathrm{pkr}$ & 17 & $8.5 \%$ \\
\hline & $\begin{array}{l}25,000 \text { pkr to } 50,000 \\
\text { pkr }\end{array}$ & 90 & $45 \%$ \\
\hline & $\begin{array}{l}51,000 \mathrm{pkr} \text { to } 75,000 \\
\mathrm{pkr}\end{array}$ & 35 & $17.5 \%$ \\
\hline & $\begin{array}{l}76,000 \text { pkr to } 100,000 \\
\text { pkr }\end{array}$ & 22 & $11 \%$ \\
\hline & $\begin{array}{l}\text { More than } 100,000 \\
\text { pkr }\end{array}$ & 36 & $18 \%$ \\
\hline
\end{tabular}


Above is the demographic information of 200 respondents with male $(69 \%)$ and female $(31 \%)$, less than 25 years $(27.5$ $\%), 25-30$ years $(48.5 \%), 31-35$ years $(17.5 \%), 36-40$ years $(4 \%)$, and Greater than $40(2.5 \%)$. For qualification, bachelors are $(36.5 \%)$, masters are (56.5\%), M.Phil/PhD are $(5.5 \%)$ and others are $(1.5 \%) .20 \%$ are less than one year of experience, $26.5 \%$ are $2-5$ years of experience, $9 \%$ are 5 6 years of experience, $39 \%$ are $6-10$ years of experience and $5.5 \%$ are More than 10 years of experience. $42.5 \%$ of respondents are of Managerial Level, 32.5\% are of Assistant Level, $18 \%$ are of Officer Level, and $7 \%$ are from other levels or grades in the Organization. For Sector in which respondents' organization falls, $22.5 \%$ are from textile sector, $32.5 \%$ are from Banking and Finance Sector, $17.5 \%$ are from Manufacturing Sector, $12 \%$ are from software and $15.5 \%$ are from other sectors.

Table 2: Mean, Standard error and Standard Deviations

\begin{tabular}{|c|c|c|c|c|}
\hline Variables & Questions & Mean & S.E & $\begin{array}{l}\text { Std. } \\
\text { Dev }\end{array}$ \\
\hline \multirow[t]{4}{*}{$\begin{array}{l}\text { Transfer of } \\
\text { training }\end{array}$} & $\begin{array}{l}\text { Using the new knowledge } \\
\text { and skills acquired from } \\
\text { the training has helped me } \\
\text { improve my work. }\end{array}$ & 3.99 & 0.067 & 0.95 \\
\hline & $\begin{array}{l}\text { I can accomplish my tasks } \\
\text { faster than before training. }\end{array}$ & 3.51 & 0.073 & 1.04 \\
\hline & $\begin{array}{l}\text { The quality of my work has } \\
\text { improved after using new } \\
\text { knowledge and skills } \\
\text { acquired from the training } \\
\text { course. }\end{array}$ & 3.99 & 0.064 & 0.91 \\
\hline & $\begin{array}{l}\text { I make fewer mistakes in } \\
\text { the job activities after } \\
\text { acquiring new skills from } \\
\text { training. }\end{array}$ & 3.59 & 0.070 & 0.99 \\
\hline \multirow{4}{*}{$\begin{array}{l}\text { Perceived } \\
\text { organizatio } \\
\text { nal support }\end{array}$} & $\begin{array}{l}\text { My organization cares } \\
\text { about my opinions. }\end{array}$ & 3.48 & 0.072 & 1.02 \\
\hline & $\begin{array}{l}\text { My organization strongly } \\
\text { considers my goals and } \\
\text { values. }\end{array}$ & 3.41 & 0.074 & 1.05 \\
\hline & $\begin{array}{l}\text { Help is available from my } \\
\text { organization when i have a } \\
\text { problem. }\end{array}$ & 3.68 & 0.072 & 1.02 \\
\hline & $\begin{array}{l}\text { My organization is willing } \\
\text { to help me when i need a } \\
\text { special favour. }\end{array}$ & 3.46 & 0.072 & 1.03 \\
\hline \multirow[t]{5}{*}{$\begin{array}{l}\text { Motivation } \\
\text { to learn }\end{array}$} & $\begin{array}{l}\text { I am very much satisfied } \\
\text { with the training courses } \\
\text { taken. }\end{array}$ & 3.62 & 0.067 & 0.95 \\
\hline & $\begin{array}{l}\text { Training will increase my } \\
\text { personal productivity. }\end{array}$ & 3.96 & 0.068 & 0.96 \\
\hline & $\begin{array}{l}\text { I probably find } \\
\text { opportunities for learning } \\
\text { new skills motivating. }\end{array}$ & 3.88 & 0.068 & 0.96 \\
\hline & $\begin{array}{l}\text { I get excited when I think } \\
\text { about trying to use my new } \\
\text { learning on my job. }\end{array}$ & 3.93 & 0.072 & 1.02 \\
\hline & $\begin{array}{l}\text { I believe that training helps } \\
\text { me do my current job } \\
\text { better. }\end{array}$ & 3.79 & 0.072 & 1.03 \\
\hline
\end{tabular}

\begin{tabular}{|l|l|c|c|c|}
\hline Training & $\begin{array}{l}\text { I often take training courses } \\
\text { related to my job. }\end{array}$ & 3.35 & 0.072 & 1.02 \\
\cline { 2 - 5 } & $\begin{array}{l}\text { There is a continuing } \\
\text { training plan in my } \\
\text { company. }\end{array}$ & 3.33 & 0.076 & 1.08 \\
\cline { 2 - 5 } & $\begin{array}{l}\text { Training involves } \\
\text { participatory learning } \\
\text { method. }\end{array}$ & 3.60 & 0.067 & 0.95 \\
\cline { 2 - 5 } & $\begin{array}{l}\text { Training is based on step- } \\
\text { by-step instruction moving } \\
\text { from basic to advanced } \\
\text { learning content. }\end{array}$ & 3.74 & 0.068 & 0.96 \\
\cline { 2 - 5 } & $\begin{array}{l}\text { Training sessions are held } \\
\text { by demonstration of } \\
\text { specific examples. }\end{array}$ & 3.62 & 0.066 & 0.94 \\
\hline
\end{tabular}

There are 4 items in the questionnaire for dependent variable i.e. Transfer of Training. All mean values of the items for 'Transfer of Training' lie within the range of 3.51-3.99. The mean value for both first and third item is 3.99 which is above average and the standard deviation for both are 0.95 and 0.91 respectively that reflects that these values are much closer to the mean of data set. The mean value of second and fourth item is 3.51 and 3.59 respectively and standard deviation is 1.04 and 0.99 respectively. Lower standard deviation shows that values are not dispersed away from the mean of data set and above average mean shows that responses are more towards 'Strongly agree' in the five point likert scale.

The mean value of 4 items of independent variable i.e. 'perceived organizational support' lies in the range of 3.41-3.68. The mean value of $3^{\text {rd }}$ item with standard deviation 1.02. Same goes for $1^{\text {st }}, 2^{\text {nd }}$ and $4^{\text {th }}$ item that shows mean values $3.48,3.41$ and 3.46 respectively with standard deviation 1.02, 1.05 and 1.03 respectively. Here mean values are above average but lower than that of 'transfer of training' but standard deviation is slightly more than that of 'Transfer of Training'.

The mean values of five items of independent variable i.e. 'Motivation to Learn' lies in the range of 3.62-3.96 with standard deviations in the range of 0.95-1.03. Here mean values are above average with low standard deviations which shows responses are more towards 'Strongly agree' in five point likert scale and less dispersed from mean value.

The mean values of five items of independent variable i.e. 'Training Design' lies in the range of 3.33-3.74 with standard deviations in the range of 0.94 to 1.08 . Mean values are above average but not more than that of 'Motivation to Learn' and 'Transfer of Training'. Here standard deviations are low but higher than that of other variables.

\section{Structural Equation Modeling}

Structural equation model (SEM) was used to test the hypotheses which has been done by smart PLS software. A technique has been used known as bootstrapping to test all the direct and indirect effects on variables (Shrout \& Bolger, 2002). 


\section{Measurement of Outer Mode}

In Smart PLS Software, test of convergent and discriminant validity is conducted to check the reliability and validity of the instruments and this is the ultimate aim of measure of fit in measurement model.

\section{Composite Reliability}

Reliability implies stability of questionnaire outcomes. For the similar target population, at whatever point the questioner reutilize the questionnaire it will give similar outcome. It demonstrates inside consistency \& repeatability of the survey is high. The primary measure for unwavering quality is to maintain a strategic distance from unfairness in research. In this manner, it tends to be improved by testing the pursuit procedure and investigation, as is done utilizing diverse research and examination techniques or different researchers. This also incorporates the dependability and legitimacy of the exploration.

Table 3: Composite reliability outcomes

\begin{tabular}{|c|c|}
\hline Variables & $\begin{array}{c}\text { Composite } \\
\text { Reliability }\end{array}$ \\
\hline Motivation to Learn & 0.932 \\
\hline Perceived Organizational Support & 0.918 \\
\hline Training Design & 0.890 \\
\hline Transfer of Training & 0.872 \\
\hline
\end{tabular}

\section{Factor loadings significant}

Below is the table of confirmatory factor analysis with the loadings. Variables with the loading of 0.5 are considered as strong loading variables whereas the variables with the loading of below 0.5 are considered as weak loading variables and it is better to remove them from table.

Table 4: Confirmatory factor analysis with the loadings

\begin{tabular}{|l|l|c|c|c|}
\hline Variables & Constructs & $\begin{array}{c}\text { Items } \\
\text { loading }\end{array}$ & $\begin{array}{c}\text { T } \\
\text { Statistics }\end{array}$ & $\begin{array}{c}\text { P } \\
\text { Values }\end{array}$ \\
\hline Motivation to & Motivation_1 & 0.794 & 22.591 & 0.000 \\
\cline { 2 - 5 } & Motivation_2 & 0.887 & 37.624 & 0.000 \\
\cline { 2 - 5 } & Motivation_3 & 0.884 & 39.606 & 0.000 \\
\cline { 2 - 5 } & Motivation_4 & 0.853 & 26.464 & 0.000 \\
\cline { 2 - 5 } & Motivation_5 & 0.864 & 36.246 & 0.000 \\
\hline Perceived & OrgSupport_1 & 0.858 & 28.909 & 0.000 \\
\cline { 2 - 5 } Srganizational & OrgSupport_2 & 0.877 & 35.874 & 0.000 \\
\cline { 2 - 5 } & OrgSupport_3 & 0.899 & 56.166 & 0.000 \\
\cline { 2 - 5 } & OrgSupport_4 & 0.795 & 23.522 & 0.000 \\
\hline Training & TDesign_1 & 0.716 & 16.868 & 0.000 \\
\cline { 2 - 5 } Design & TDesign_2 & 0.682 & 12.760 & 0.000 \\
\cline { 2 - 5 } & TDesign_3 & 0.852 & 32.467 & 0.000 \\
\cline { 2 - 5 } & TDesign_4 & 0.839 & 31.852 & 0.000 \\
\cline { 2 - 5 } & TDesign_5 & 0.834 & 32.424 & 0.000 \\
\hline Transfer of & Transfer_1 & 0.871 & 34.716 & 0.000 \\
\cline { 2 - 5 } Training & Transfer_2 & 0.695 & 9.772 & 0.000 \\
\cline { 2 - 5 } & Transfer_3 & 0.877 & 37.232 & 0.000 \\
\cline { 2 - 5 } & Transfer_4 & 0.723 & 13.105 & 0.000 \\
\hline
\end{tabular}

It is shown above that the constructs related to independent variables i.e. Motivation to Learn, Perceived Organizational Support and Training Design as well as dependent variable i.e. Transfer of Training, are having loading values more than 0.70 except TDesign_2 and Transfer_2 that has loading values of 0.682 and 0.695 respectively which are also above 0.5 . Therefore, it indicates strong loading values. On the other hand, $t$ values are more than 1.96 for all constructs along with $p$ values that are less than 0.05 i.e. above $99 \%$ confidence.

\section{Convergent Validity}

Convergent validity is established when AVE values are greater than 0.5. Fornell \& Larcker (1981) states that when the variance extracted values are greater than 0.5 then loadings are good and are termed as effective for the study but when they are less than 0.5 , they are termed as less effective for the study.

Table 5: Convergent validity display and result

\begin{tabular}{|l|c|c|c|c|}
\hline Variables & $\begin{array}{c}\text { Cronbach's } \\
\text { Alpha }\end{array}$ & Rho_A & $\begin{array}{c}\text { Composite } \\
\text { Reliability }\end{array}$ & $\begin{array}{c}\text { Average } \\
\text { Variance } \\
\text { Extracted } \\
\text { (AVE) }\end{array}$ \\
\hline $\begin{array}{l}\text { Motivation } \\
\text { to Learn }\end{array}$ & 0.909 & 0.912 & 0.932 & 0.735 \\
\hline $\begin{array}{l}\text { Perceived } \\
\text { Organizational } \\
\text { Support }\end{array}$ & 0.881 & 0.886 & 0.918 & 0.736 \\
\hline $\begin{array}{l}\text { Training } \\
\text { Design }\end{array}$ & 0.847 & 0.864 & 0.890 & 0.620 \\
\hline $\begin{array}{l}\text { Transfer of } \\
\text { Training }\end{array}$ & 0.805 & 0.836 & 0.872 & 0.633 \\
\hline
\end{tabular}

Reliability was evaluated using Cronbach's Alpha. Values of each variable was above the threshold value i.e. 0.70 . This is the range of acceptable reliability value. The acceptable value of Cronbach's alpha is 0.70 to 1 . A questionnaire is said to be reliable and valid if Cronbach's alpha lies in above declared range. The number of items for one dependent variable 'Transfer of Training' are 4 and the Cronbach's Alpha is 0.805. This is showing a reliable Cronbach's Alpha. The Cronbach's Alpha for first independent variable 'motivation to learn' has a value 0.909 with number of items 5 . This is also a reliable value. The Cronbach's Alpha for the $2^{\text {nd }}$ independent variable 'Perceived Organizational Support' is 0.881 with number of items 4 . This value is also reliable if compared to the range (0.7-1.00). The Cronbach's Alpha for the $3^{\text {rd }}$ independent variable 'Training Design' has a value 0.847 with number of items 5 . Hence, all 4 variables are reliable including dependent as well as independent variables.

Above table clearly shows that AVE values are greater than 0.5 for all the variables including Motivation to Learn, Perceived Organizational Support, Training Design and Transfer of Training. So, we can say that it supports convergent validity. 


\section{Discriminant validity}

When the variables are having an AVE values more than 0.5 , discriminant validity results are satisfactory (Chin, 1998). Discriminant Validity tests are being conducted in order to see whether non-related ideas or measurements are in fact unrelated or not.

Table 6: Discriminant validity results

\begin{tabular}{|l|c|c|c|c|}
\hline Variables & $\begin{array}{c}\text { Motivation } \\
\text { to Learn }\end{array}$ & $\begin{array}{c}\text { Perceived } \\
\text { Organizational } \\
\text { Support }\end{array}$ & $\begin{array}{c}\text { Training } \\
\text { Design }\end{array}$ & $\begin{array}{c}\text { Transfer } \\
\text { of } \\
\text { Training }\end{array}$ \\
\hline $\begin{array}{l}\text { Motivation } \\
\text { to Learn }\end{array}$ & 0.857 & 0.858 & & \\
\hline $\begin{array}{l}\text { Perceived } \\
\text { Organizational } \\
\text { Support }\end{array}$ & 0.608 & 0.596 & 0.788 & \\
\hline $\begin{array}{l}\text { Training } \\
\text { Design }\end{array}$ & 0.769 & 0.495 & 0.655 & 0.796 \\
\hline $\begin{array}{l}\text { Transfer of } \\
\text { Training }\end{array}$ & 0.754 & & & \\
\hline
\end{tabular}

In the above table, it clearly shows that discriminant validity results are satisfactory, which explains that minimum $50 \%$ variance was took by the variables.

Table 7: Model fit measures

\begin{tabular}{|l|c|c|}
\hline \multicolumn{3}{|c|}{ Fit Summary } \\
\hline & Saturated Model & Estimated Model \\
\hline SRMR & 0.072 & 0.072 \\
\hline d_ULS & 0.895 & 0.895 \\
\hline d_G & 0.332 & 0.332 \\
\hline Chi-Square & 393.396 & 393.396 \\
\hline NFI & 0.841 & 0.841 \\
\hline
\end{tabular}

\section{HYPOTHESIS TESTING}

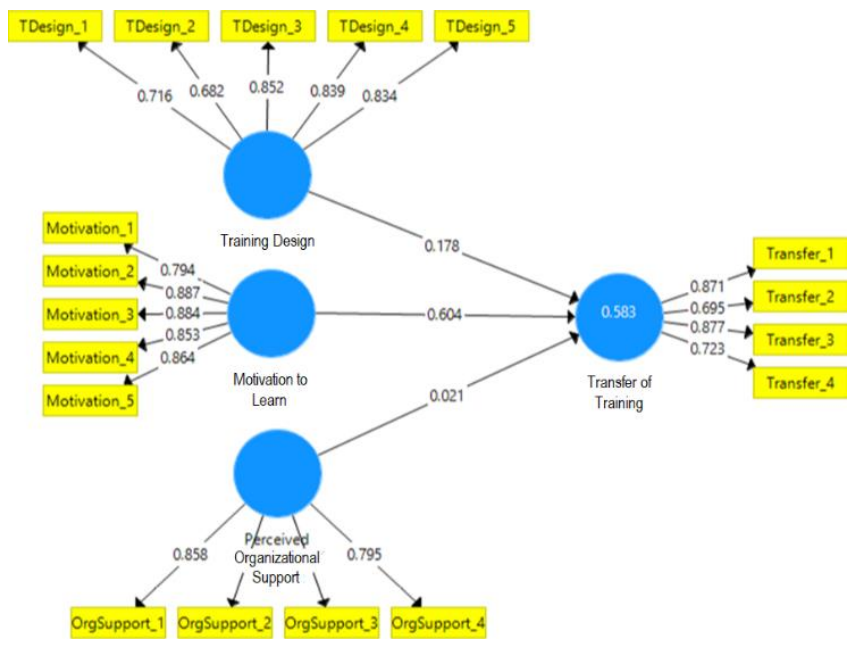

Figure 2: Pls Algorithm

Above model shows that $\mathrm{R}$ square value is 0.178 that determines the variation caused in Transfer of Training due to Training Design. This clearly specifies that Training Design has $17.8 \%$ impact on Transfer of Training. Next, model shows that $\mathrm{R}$ square value is 0.604 that determines the variation caused in Transfer of Training due to Motivation to Learn. This clearly specifies that Motivation to Learn has $60.4 \%$ impact on Transfer of Training which is the highest of them all. Next, model shows that $R$ square value is 0.021 that determines the variation caused in Transfer of Training due to Perceived Organizational Support. This clearly specifies that Perceived Organizational Support has 2.1\% impact on Transfer of Training.

Table 8: Results of hypothesis

\begin{tabular}{|l|c|c|c|c|}
\hline Hypothesis & STDEV) & $\begin{array}{c}\text { T } \\
\text { Stat }\end{array}$ & $\begin{array}{c}\text { P } \\
\text { Values }\end{array}$ & Decision \\
\hline $\begin{array}{l}\text { H1: There is a direct impact } \\
\text { of motivation to learn on } \\
\text { transfer of OJT training. }\end{array}$ & 0.071 & 8.545 & 0.000 & Supported \\
\hline $\begin{array}{l}\text { H2: There is a direct impact } \\
\text { of perceived organizational } \\
\text { support on transfer of OJT } \\
\text { training. }\end{array}$ & 0.072 & 0.298 & 0.766 & $\begin{array}{c}\text { Not } \\
\text { Supported }\end{array}$ \\
\hline $\begin{array}{l}\text { H3: There is a direct impact } \\
\text { of training design on } \\
\text { transfer of OJT training }\end{array}$ & 0.081 & 2.206 & 0.028 & Supported \\
\hline
\end{tabular}

The independent variables (Motivation to Learn and Training Design) are having positive relationship with Transfer of Training as both of the p-values are less than 0.05 which confirms that both Motivation to Learn and Training Design will have a direct impact on Transfer of Training. But the independent variable i.e. perceived organizational support does not show the positive relationship with Transfer of Training as the $p$-value of this variable is more than 0.05 .

In PLS-SEM, bootstrapping is one of the key stride, which gives the data of constancy of factor guesstimate. Subtests are drawn everywhere from the first example including substitution, in this process (Hair et al., 2017).

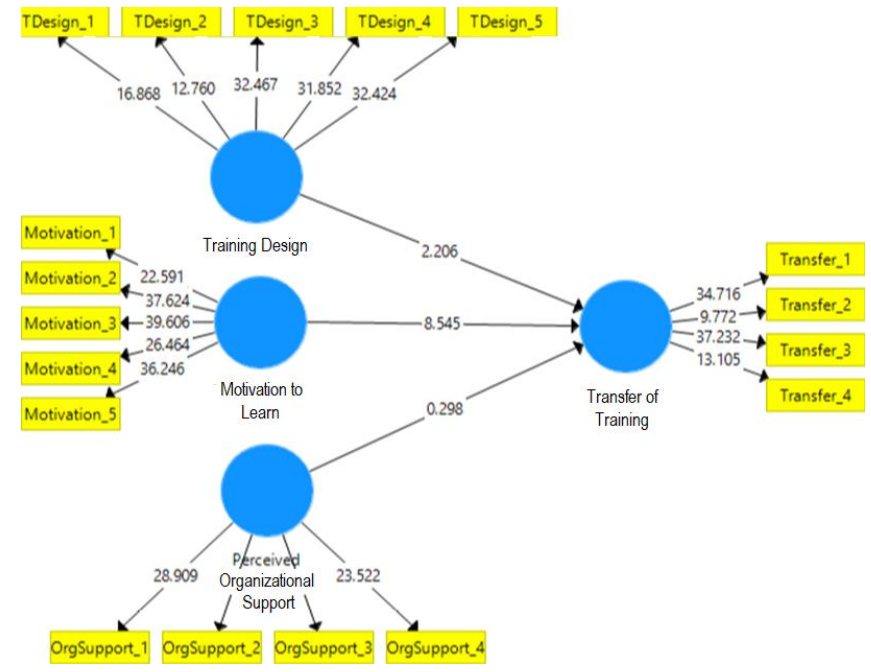

Figure 3: PLS Bootstrapping

$\mathrm{T}$-values and their significance can be seen in the above table and model. Hypothesis is accepted if the level of significance is less than 0.05 and $t$-value is greater than 
1.96. But if the level of significance is more than 0.05 and $\mathrm{t}$-value is greater than 1.96, then hypothesis is rejected and null hypothesis is accepted. Here, we see that Motivation to Learn and Training Design both have the $\mathrm{t}-$ values $>1.96$ with level of significance less than 0.05 . So, our hypothesis of these two variables are accepted that, There is a direct impact of Motivation to Learn on transfer of OJT training and There is a direct impact of Training Design on Transfer of OJT training. The $\mathrm{t}$-value of Perceived Organizational Support is less than 1.96 and level of significance is more than 0.05 , therefore our hypothesis cannot be accepted and it shows that there is no direct impact of Perceived Organizational Support on transfer of OJT training.

\section{Discussions}

\section{Critical Debate}

Transfer of OJT training play an important role in determining the effectiveness of OJT training provided to employees in an organization. According to the results it was observed that most of the participants belonged to Managerial Level and Assistant levels, and were male mostly. It was observed through the literature review, that motivation to learn plays an important role in transfer of training. The results of this research highlight that the motivation of different organizations' employees in Pakistan also plays a significant role in the transfer of OJT training at work. They were found to have strong understanding of the importance of OJT training and development in having a successful career development. Employee's motivation to learn new things can increase their confidence to acquire new skills and apply their learned knowledge in performing different tasks. Furthermore, they think that OJT training helps them in doing their work in a better way. These findings were supported by Kim-Soon et al. (2014) and Maung \& Chemsripong (2014) highlighting a significant impact of motivation to learn on the transfer of training. Employees who understand the importance of training are more likely to transfer the OJT training more effectively as compared to others.

Furthermore, this study revealed that training design also have a significant impact on transfer of OJT training in workplaces in Pakistan. This finding significantly matches from the findings of previous studies. According to Wawira (2014) and Bhatti et al. (2013), different factors of training deign (content, delivery, examples, etc.) play a significant role in effective transfer of training. According to the employees, the OJT programs include practical demonstrations. Furthermore, employees find content to apply to their work not that much difficult as it is easily available and can be easily comprehend. The employees in workplaces in Pakistan were not found to face difficulty in accessing to training material and these employees are able to relate their OJT trainings. Moreover, Bhatti \& Kaur
(2010) also highlighted that content validity of the training design plays an important part in increasing the selfefficacy of employees, which increases the effectiveness of the training program. Velada \& Caetano (2007) also showed a positive impact of training design on the transfer of training.

Lastly, the study revealed that Perceived Organizational Support does not have any significant impact on transfer of OJT training at workplaces in Pakistan. This finding significantly contradicts from the findings of previous studies. On the contrary, Nawaz et al. (2013) and Baldwin et al. (2009) have revealed that management can provide support in different ways, such as by providing feedback, by actively participating in the trainings, by attending trainings, and by encouraging employees to come up with new ideas that can improve the working processes. The extent to which supervisors' support as well their perception about a trainee may be an important factor affecting individual ability to transfer the knowledge acquired during OJT training to the workplace. There are a number of ways through which management provides support for transfer of OJT training. Previous Studies demonstrate that supervisors support 'transfer of OJT training' through empowering their employees. Here Employees at workplaces in PAKISTAN highlighted that they are not properly rewarded even if they successfully transfer their learnings to their work. Supervisors does not really help their employees to a great extent in application of what employees have learnt from their on-the-job trainings while performing their duties.

\section{ConCLUSION}

Training plays an important role in the development of employees at different organizations in Pakistan. However, there are a number of factors identified through literature that affect the transfer of knowledge gained during OJT trainings to the work or task. Heavy budgets training goes in vain mostly when they are not transferred or implemented by trainees on their jobs due to various factors.

The training transfer is a difficult challenge for organizations that are focusing on outcomes from the investments on training programs (Chiaburu et al., 2010b). In a study, researchers found that, the new learned knowledge, skills and attitudes had used by only 62 percent of employees right after training. After 6 months, it fell to 44 percent and further decreased to 34 percent after one year duration (Saks \& Belcourt, 2006). A recent study shows that the trainees' transfer performance fell within three weeks after training indicated by 56 trainees (Vermeulen \& Admiraal, 2009).

Although, a number of studies have been focused on transfer of training, the little evidence was available on both individual as well as organizational factors that have a significant impact on transfer of skills and knowledge on 
job (Bhatti \& Kaur, 2010; Cheng \& Ho, 2001). This is the basic gap that is analyzed in the previous studies of transfer of training.

Different studies focus on single factor of organizational context i.e. Impact of organizational support on transfer of training. For example, Colquitt et al. (2000) found that there is a positive impact of supportive transfer climate on transfer of training. In contrast, there is a negative impact of unsupportive transfer climate on transferring the new knowledge at work place (Aguinis \& Kraiger, 2009).

Therefore, the study presented in this paper is conducted to help address this gap by examining the combined effects of motivation to learn (a trainee characteristic), perceived organizational support (POS) (a work environment factor) and training design (a training characteristic) on transfer of training at the workplaces in Pakistan. It will then cover both individual as well as organizational factors which are not previously studied in one research in Pakistan.

This research is focused on analysing the factors that affect transfer of OJT training at workplaces in Pakistan. This study adopted a quantitative research method, and data was collected through survey questionnaires. In Pakistan, there is a dynamic work environment so a sample of 200 participants is surveyed from different sectors. Data is analysed through SMART PLS software. Based on the research findings it was concluded that 'Perceived Organizational Support' does not have any significant impact on the transfer of OJT training at workplaces in Pakistan. In Pakistan, the level of Organizational support is not to that satisfactory level perceived by employees. However, 'motivation to learn' and 'Training Design' have a significant impact on transfer of OJT training at workplaces. This shows that even though, if the organization support is not available here, the motivation to learn new things and to implement it to the workplace, and effectively designed training can overcome the issues. When employees are motivated, their job satisfaction increases and they implement their knowledge gained during training to their jobs without any hesitation as their feeling of belongingness to their workplaces increases. Furthermore, it also concludes that it is very important to provide a conducive work environment that motivates people to learn new things and come up with new ideas to solve different work-related issues.

\section{Practical Implications and Recommendations}

Based on the research findings, it shows that OJT is being carried out without any management and supervisors' support that helps the trainees implement what they have learnt. Hence, it is important for the organizations to improve this aspect in future. Management can provide support in different ways, such as by providing feedback, by actively participating in the trainings, by attending trainings, and by encouraging employees to come up with new ideas that can improve the working processes. So, the organizations in different sectors in Pakistan need to improve their support and guidance system by managers and supervisors. Studies demonstrate that eliminating barriers to application and transfer of OJT training in the work environment is the most significant form of support provided by supervisors and top management. Supervisors should encourage their employees to apply their learned knowledge in order to devise new ways for performing their tasks. It is also important to make the trainees comfortable by providing friendly and supportive environment in which they could ask anything at any time to lift their performance to the highest levels. Management should support and provide guidance to employees at every level in order to achieve strategic goals of the company.

\section{LIMITATIONS OF THE STUDY}

There are several limitations of this study. One of the major limitation for the study is time and budget constraints. Moreover, the study is limited to quantitative/qualitative survey design as a result of budget constraints and does not include observatory analysis which does not allow the researcher to ask detailed questions from the research participants. Another limitation is that not every sector from Pakistan is covered in this research due to time and accessibility issue. Sample size is 200 which couldn't cover the small sectors but major business sectors are included in this study. NonProbability sampling i.e. Convenience Sampling technique is used in data collection.

\section{REFERENCES}

A.R. Elangovan, \& Karakowsky, L. (1999). The Role of Trainee and Environmental Factors in Transfer of Training. Leadership and Organizational Development Jornal, 20(5), 268276.

Acton, T., \& Golden, W. (2003). Training the Knowledge Worker: A descriptive study of training practices in Irish Software Companies. Journal of European Industrial Training, 27(2/3/4), 137-146.

Aguinis, H., \& Kraiger, K. (2009). Benefits of Training and Development for individuals and teams, organizations and society. Annual Review of Psychology, 60, 451-474.

Ahmed, F. and Siddiqui, D. A. (2019) "The Impact of CRM on Innovation Capabilities: A Study on Industries of Pakistan", American Journal of Trade and Policy, 6(3), pp. 7784. doi: 10.18034/ajtp.v6i2.350.

Al-Eisa, A. S., Furayyan, M. A., \& Alhemoud, A. M. (2009). An Empirical examination of the effects of self-efficacy, supervisor support and motivation to learn on transfer intention. Management Decision, 47(8), 1221-1244.

Amabile, T. (1996). Creativity in Context (Boulder, CO, Westview Press). westview press. 
Awoniyi, E., Griego, O., \& Morgan, G. (2002). PersonEnvironment Fit and Transfer of Training. International Journal of Training and Development, 6(1), 25-35.

Axtell, C., Maitlis, S., \& Yerta, S. (1997). Predicting immediate and longer term transfer of training. Personnel Review, 26, 201-213.

Baharim. (2005). Self efficacy: Toward a Unifying Theory of Behavioral Change. Psychological Review, 84, 191-215.

Baldwin, T. T., \& Ford, J. K. (1988). Transfer of Training: a review and directions for future research. Personnel Psychology, 41, 63-105.

Baldwin, T. T., Ford, K. J., \& Blume, B. D. (2009). Transfer of Training 1988-2008: an updated review and agenda for future research. International Review of Industrial and Organizational Psychology, 24, 41-70.

Baron, M., \& Kenny, D. A. (1986). The moderator-mediator variable distinction in social psychological research. Journal of Personality and social Psychology, 51(6), 1173-1182.

Bates, R. A., Holton III, E. F., Seyler, D. L., \& Carvalho, M. A. (2000). The Role Of Interpersonal Factors in the application of Computer based Training in an Industrial Setting. Human Resource Development International, 3, 19-42.

Bell, B. S., \& Ford, J. K. (2007). Reactions to skill assessment: The forgotten factor in explaining motivation to learn. Human Resource Development Quarterly, 18(1), 33-62.

Bhatti, M. A., \& Kaur, S. (2009). Factors Affecting Transfer of Training: A Fresh Review. 12th International Business Information Management Conferenece (IBIMA). Kuala Lumpur.

Bhatti, M. A., \& Kaur, S. (2010). The role of individual and training design factors on Training Transfer. Journal Of European Industrial Training, 34(7), 656-672.

Bhatti, M. A., Kaur, S., \& Battour, M. M. (2013). Training Transfer and Transfer Motivation in the Malaysian Banking Sector. Global Business and Organizational Excellence, 33(1), 40-57.

Bhuvanaiah, T., \& Raya, R. (2015). Mechanism of Improved Performance. Intrinsic Motivation and employee performance, 12(4), 92.

Brinkerhoff, R. O., \& Montesino, M. U. (1995). Partnership for Training Transfers: Lessons from a corporate study. Human Resource Development Quarterly, 6(3), 263-274.

Broad, M. L., \& Newstrom, J. W. (1992). Transfer Of Training: Action Packed Strategies to Ensure High Payoff from Training Investments. Addison Wesley.

Burke, L. A., \& Hutchins, H. M. (2007). Training Transfer: an integrative literature review. Human Resource Development Review, 6(3), 263-296.

Burke, L. A., \& Saks, A. M. (2009). Accountability in Training Transfer: Adapting Schlenker's Model Of Responsibility to a persistent but solvable Problem. Human Resource Development Review, 8(3), 382-402.

Carmines, E. G., \& Zeller, R. A. (1979). Reliability and Validity Assessment. Thousand Oaks, 17.

Cheng, E. W., \& Ho, D. C. (2001). The Influence Of Job and Career attitudes on Learning Motivation and Transfer. Career Development International, 6(1), 20-28.
Cheng, E., \& Hampson, I. (2008). Transfer of Training: a review and new insights. International Journal of Management Reviews., 10(4), 327-341.

Chiaburu, D. S., \& Lindsay, D. R. (2008). Can Do or will Do? The importance of Self-efficacy and instrumentality for Training Transfer. Human Resource Development International, 11, 199206.

Chiaburu, D. S., \& Marinova, S. V. (2005). What predicts Skill Transfer? An exploratory study of Goal Orientation, training Self Efficacy and Organizational Support. International Journal Of Training and Development, 9, 110-123.

Chiaburu, D. S., Dam, K. V., \& Hutchins, H. M. (2010). Social Support in the workplace and Training Transfer: a longitudinal analysis. International Journal of Selection and Assessment, 18(2), 187-200.

Chiaburu, D. S., Sawyer, K. B., \& Thoroughgood, C. N. (2010b) Transferring more than learned in Training: employees' and managers' (over) generalization of skills. International Journal of Selection and Assessment, 18(4), 380-393.

Chin, W. W. (1998). The Partial Least Squares approach for structural equation modeling. (G. A. Marcoulides, Ed.) US: Lawrence Erlbaum Associates Publishers.

Clark, R. E., \& Voogel, A. (1985). Transfer Of Training Principles for Instructional Design. Educational Technology Research and Development, 33(2), 113-123.

Colquitt, J. A., LePine, J. A., \& Noe, R. A. (2000). Toward an integrative theory of Training Motivation: a meta-analytic path analysis of 20 years of research. Journal of Applied Psychology, 85(5), 678.

Cowling, A., \& Mailer, C. (2013). Managing Human Resources. Routledge.

David, F. (1997). Concepts of strategic management (6th ed.). New Jersey, USA: Prentice Hall.

Dragoni, L. (2005). Understanding the emergence of state goal orientation in organizational work groups: the role of leadership and multilevel climate perceptions. Journal of Applied Psychology, 90(6), 1084-1095.

Fernandez-Salinero, C. (1999).

Ford, D. K., \& Weissbein, D. A. (1997). Transfer of Training: an updated review analysis. Performance Improvement Quarterly, $10(2), 22-41$

Fornell, C., \& Larcker, D. F. (1981). Evaluating Structural Equation Models with unobservable variables and measurement Error. Journal of Marketing Research, 18(1), 3950.

Foxon, M. (1993). A Process Approach to the Transfer of Training: Part 1: the impact of motivation and supervisor support on transfer maintenance.

Foxon, M. (1994). A Process Approach to the Transfer of Training: Part 2: Using action planning to facilitate the transfer of training.

Gegenfurtner, A., Festner, D., Gallenberger, W., Lehtinen, E., \& Gruber, H. (2009). Predicting autonomous and controlled motivation to transfer training. International Journal of Training and Development, 13(2), 124-138.

Geilen, E. W. (1996). Transfer of Training in Corporate Setting: testing a model. Academy Of Human Resource Development 
International Research Conference 1996, (pp. 434-441). Minniapolis.

Gill, A. J., Molina, J. A., \& Ortega, R. (2016). Determinants of Training Transfer in the wine industry: conceptual hypotheses and results for Rioja (Spain). Journal of Wine Research, 27(1), 65-83.

Gilpin-Jackson, Y., \& Bushe, G. R. (2007). Leadership Development Training Transfer: a Case Study of Post Training Determinants. Journal Of Management Development, 26(10), 980-1004.

Greenhaus, J. G., Callanan, G. A., \& Godshalk, V. M. (2000). Career Management (3rd ed.). Newyork: The Dryden Press.

Greenhaus, J. H., Callanan, G. A., \& Godshalk, V. M. (2000). The Greenhaus et al. Model of Career Management (3rd ed.). The Dryden Press.

Hair . (2010).

Hair, J. F., Jr., Sarstedt, M., Matthews, L. M., \& Ringle, C. M. (2016). Identifying and treating unobserved heterogenity with FIMIX PLS: Part-1 Method. European Business Review, 28(2), 63-76

Hair, J. F., Matthews, L. M., Matthews, R. M., \& Sarstedt, M. (2017). PLS-SEM or CB-SEM: updated guidelines on which method to use. Int. J. Multivariate Data Analysis, 107-123. Retrieved

from https:/ / www.google.com/url?sa=t\&rct=j\&q=\&esrc=s\&so urce $=$ web\&cd $=1 \& c a d=$ rja \&uact $=8 \& v e d=2$ ahUKEwj $8 \mathrm{~mJ} 316$ LTiAhWBxIsKHbO2ApsQFjAAegQIBxAC\&url=https\%3A $\% 2 \mathrm{~F} \% 2 \mathrm{Fwww}$.researchgate.net $\% 2$ Fprofile $\% 2$ FThien_Sang Lim\%2Fpost $\% 2$ FWhat_papers_or_manuals_do_you_recom mend_the_most_to

Hanus, M. D., \& et al. (2015). Assessing the effects of gamification in the classroom. A longitudinal study on intrinsic motivation, social comparision, satisfaction, effort and academic performance. 80, 152-161.

Hayes, A. F. (2013). Introduction to Mediation, Moderation and Conditional Process Analysis: A regression based approach. Journal Of Educational Measurement, 51(3), 335-337.

Henley, B., \& et al. (2002). Motivation Questionnaire Manual and users' guide.

Herzberg, F., Mausner, \& Synderman. (1959). The Motivation to Work. John Wiley and Sons.

Janssen, O., \& Van Yperen, N. (2004). Employees' goal orientations, the quality of leader-member exchange and the outcomes for job performance and job satisfaction. Academy of Management Journal, 47(3), 368-384.

Kauffeld, S., \& Lehmann Willenbrock, N. (2010). Sales Training: effects of spaced practice and Training Transfer. Journal Of European Industrial Training, 34(1), 23-37.

Kia, N., \& Ismail, I. B. (2013, September). The Relationship between Environmental Characteristics and Training Transfer. International Journal of Business and Social Science, IV(12), 196-203.

Kim-Soon, N., Ahmad, N., \& Abd Rahman Ahmad. (2014). Moderating Effects Of WorK Environment on Motivation to Learn and Perceived Training Transfer: Empirical Evidence from a Bank. Australian Journal of Basic and Applied Sciences, 8(6), 344-361.
Kinnunen, U., Feldt, T., \& Makikangas, A. (2008). Testing the effort-award imbalance model among finnish Managers : The role of Perceived Organizational Support. Journal of Occupational Health Psychology, 13(2), 114-127.

Kontoghiorghes, C. (2002). Predicting Motivation to Learn and Motivation to transfer Learning back to the job in a service organization: A new systematic model for training effectiveness. Performance Improvement Quarterly, 15, 114129.

Laker, D. (1990). Dual Dimensionality of Training Transfer. Human Resource Development Quarterly, 1(3), 209-223.

Lancaster, S., Milia, L. D., \& Cameron, R. (2013). Supervisor behaviors that facilitate training transfer. Journal of Workplace Learning, 25(1), 6-22.

Lavelle, J. J., McMahan, G. C., \& Harris, C. M. (2009). Fairness in Human Resource Management, social exchange relationships and citizenship behavior: testing linkages of the target similarity model among nurses in the United States. International Journal Of Human Resource Management, 20(12), 2419-2434.

Liao, P. Y. (2011). Linking Work-Family Conflict to Job Attitudes: the mediating Role of Social Exchange Relationships. International Journal of Human Resource Management, 22(14), 2965-2980

Lim, D. H. (2000). Training Design Factors including transfer of training to the workplace within an international context. Journal of Vocational Education and Training, 52(2), 243-258.

Lim, D. H., \& Johnson, S. D. (2002). Trainee Perceptions of Factors that influence Learning Transfer. International Journal of Training and Development, 6(1), 37-49.

Lim, D. H., \& Morris, M. L. (2006). Influence of Trainee Characteristics,instructional satisfaction and organizational climate on perceived Learning and Training Transfer. Human Resource Development Quarterly, 17(1), 85-115.

Machin, M. (2002). Planning, Managing and Optimizing Transfer of Training. Creating, Implementing and Managing effective training and development, 263-301.

Maung, K. M., \& Chemsripong, S. (2014, June). The results of the importance of supervisor support and peer support in transfer of Training. International Journal of Business, Economics and Law, 4(1), 82-88.

Nawaz, M., Shakoor, M. I., \& Pirzada, S. S. (2013). The Professional Development of Employees in Banks of Pakistan: A comparative Study of Public and Private Banks in Punjab Pakistan. International Journal Of Learning and Development, 3(5), 89-110.

Nijman, D. J., \& Gelissen, J. (2011). Direct and indirect effects of supervisor support on transfer of training. (R. F. Poell, \& M. Woerkom, Eds.) Supporting Workplace Learning, 5(springer), 89-106.

Nikandrou, I., Brinia, V., \& Bereri, E. (2009). Trainee Perceptions Of Training Transfer: an Empirical Analysis. Journal Of European Industrial Training, 33(3), 255-270.

Noe, R. (2009). Employee Training and Development (5th ed.). Boston: MA: McGraw-Hill.

Noe, R. A. (2000). Invited Reaction: Development of a Generalized Learning Transfer System Inventory. Human Resource Development Quarterly, 11(4), 361-365. 
Noe, R. A., Hollenbeck, J. R., Gerhart, B., \& Wright, P. M. (2006). Human Resource Management of a Transfer Climate Instrument. Human Resource Development Quarterly, 8(2), 95113.

O'Driscoll, M. P., \& Randall, D. M. (1999). Perceived Organisational Support, Satisfaction with rewards and Employee Job Involvement and Organizational Commitment. Journal Of Applied Psychology, 48(2), 197-209.

Park, J., \& Wentling, T. (2007). Factors associated with Transfer of Training in Workplace e-learning. Journal of Workplace Learning, 19(5), 311-329.

Quinones, M. (1997). Contextual Influences in Training. Training for a rapidly changing workforce, 177-199.

Rothwell, W. J., \& Kazanas, H. C. (1994). Improving On-the-Job Training: How to establish and operate a comprehensive OJT Program. San Francisco: Jossey-Bass.

Rouiller, J. Z., \& Golstein, I. L. (1993). The relationship between Organizational Transfer Climate and Positive Transfer of Training. Human Resource Development Quarterly, 4, 377-390.

Rowden, R. W., \& Conine, C. (2005). The impact of workplace learning on job satisfaction in small US Commercial Banks. 17(4), 215-230.

Saks, M., \& Belcourt, M. (2006). An Investigation Of Training Activities and Transfer Of Training in Organizations. Human Resource Management, 45(4), 629-648.

Saleh, B. A. (2011). Factors Affecting Transfer of Training within the Work Environment from the perception of Workers in Palestinian Government Hospitals. Nablus.

Seyler, D. L., Holton, E. F., Bates, R. A., Burnett, M. F., \& Carvalho, M. A. (1998). Factors Affecting Motivation to Transfer Training. International Journal of Training and Development, 2(1), 2-16.

Shad, I. (2008). Influence of Organizational Work Environment on Transfer Of Training in Banking Sector. National University of Modern Languages, Faculty of Advanced Integrated Studies and Research, Islamabad.

Shrout, P. E., \& Bolger, N. (2002). Mediation in experimental and non-experimental studies: New procedures and recommendations. Psychological Methods, 7, 422-445.

Tannenbaum, S. I., \& Yukl, G. (1992). Training and Development in work organizations. Annual Review of Psychology, 43, 399441.

Thayer, P. W., \& Teachout, M. S. (1995). A Climate for transfer model, Brooks Airforce Base, Ann Arbor, MI

Tracey, J. B., Hinkin, T. R., Tannenbaum, S., \& Mathieu, J. (2001). The influence of individual characteristics and the work environment on varying levels of training outcomes. Human resource development quarterly, 12(1), 5-23.

Tremblay, M., Cloutier, J., Simard, G., Chenevart, D., \& Vandenberghe, C. (2010). The role of HRM practices, Procedural Justice, Organizational Support and trust in Organizational Commitment and in-role and extra-role
Perormance. International Journal Of Human Resource Management, 21(3), 405-433.

Tsai, P., \& et al. (2007). A study on motivating employees' learning commitment in the post-downsizing era. Job satisfaction Perspective, 42(2), 157-169.

Tziner, A., Fisher, M., Senior, T., \& Weisberg, J. (2007). Effects of trainee characteristics on training effectiveness. International Journal of Selection and Assessment, 15(2), 167-174.

Tziner, A., Fisher, M., Senior, T., \& Weisberg, J. (2007). Effects of Trainee Characteristics on Training Effectiveness. International Journal Of Selection and Assessment, 15(2), 167174.

Velada, R., \& Caetano, A. (2007). Training Transfer: The mediating role of perception of learning. Journal of European Industrial Training, 31(4), 283-296.

Vermeulen, R., \& Admiraal, W. (2009). Transfer as a two-way process: testing a model. Journal of European Industrial Training, 33(1), 52-68.

Waiyaki, E. (2017). Effect of Motivation on employee performance: a case of Pam Golding Properties Limited, Nairobi, United States International University-Africa.

Wawira, N. M. (2014). Factors Affecting Transfer of Knowledge from Training to the Job among Employees of Large Commercial Banks in Kenya. University of Nairobi, Nairobi.

Whitehill, B. V., \& Mcdonald, B. A. (1993). Improving learning persistence of military personnel by enhancing motivation in a technical training program. Simulation Gaming, 24(3), 294-313.

Xiao, J. (1996). The relationship between organizational factors and transfer of training in the electronics industry in Shenzhen, China. Journal of Human Resource Development, 7(1), 55-73.

Yamkovenko, B., \& Holton, E. (2010). Toward Theoretical Model of Dispositional Influences on Transfer of Learning: a test of a structural model. Journal of Human Resource Development Quarterly, 21(4), 381-410.

Yamnill, S., \& McLean, G. N. (2001). Theories Supporting Transfer of Training. Journal of Human Resource Development Quarterly, 12(2), 195-208.

Zumrah, A. R. (2015). Examining the relationship between perceived organizational support, transfer of training and service quality in the Malaysian Public Sector. European Journal of Training and Development, 39(2), 143-160.

Zumrah, A. R., \& Boyle, S. (2015). The effects of Perceived Organizational Support and Job Satisfaction on Transfer of Training. Personnel Review, 44(2), 236-254.

Zumrah, A. R., Boyle, S., \& Fein, E. C. (2012). The Effect of Perceived Organizational Support on the Transfer of Training Outcomes to the Workplace. World Review of Business Research, 2(4), 130-147. 
Online Archive: https://abc.us.org/ojs/index.php/abr/issue/archive 